\title{
Direct Method for Detecting Small Quantities of Hepatitis B Virus DNA in Serum and Plasma Using the Polymerase Chain Reaction
}

\author{
Jerome B. Zeldis, Jae Hag Lee, Diaa Mamish, Don J. Finegold, Roul Sircar, Qihe Ling, \\ Peter J. Knudsen, I. K. Kuramoto, and Larry T. Mimms \\ University of California Davis Medical Center, Sacramento, California 95817; Abbott Laboratories, North Chicago, Illinois 60064
}

\begin{abstract}
Serum components inhibit DNA polymerase, thereby obviating direct detection of serum viral DNA sequences by the polymerase chain reaction (PCR). This has necessitated extraction of nucleic acid from sera before performing PCR and has resulted in loss of sensitivity. By adsorbing virus to a solid surface (microcentrifuge tubes or antibody coated microparticles) followed by proteinase $\mathrm{K}$ digestion, as little as three viruses per $200 \mu \mathrm{l}$ serum may be directly detected by PCR without nucleic acid extraction. The sensitivity is dependent on the surface area of the adsorptive surface and is increased by having antibodies on the adsorptive surface. The nucleic acid sequence of the amplified DNA fragments may be directly determined by the dideoxy method. Of 24 plasma samples from $\mathrm{HBsAg+}$ volunteer blood donors, HBV DNA was detected in 7 by dot blot assay, 7 by liquid hybridization, and 9 by PCR. PCR detected DNA in every sample that was positive by another assay. Analysis of serial samples of two patients with acute self-limited hepatitis B found detectable HBsAg and pre-S2 antigenemia before HBV DNA by the PCR method. These results suggest that surface antigenemia may precede viremia during acute hepatitis.
\end{abstract}

\section{Introduction}

Immunoassays for hepatitis $\mathrm{B}$ surface antigen $(\mathrm{HBsAg})^{1}$ and hepatitis $\mathrm{B}$ e antigen $(\mathrm{HBeAg})$ are unable to detect viral associated antigens at concentrations at the limit of infectivity; only a few viruses per milliliter. Filter hybridization assays for hepatitis B virus DNA (HBV DNA) can only detect 0.1 to $1 \mathrm{pg}$ (2,500 to 25,000 viruses). While some $\mathrm{HBsAg}+$ patients may not be actively producing virus and are not infectious, currently available assays are unable to distinguish these individuals from patients who have low levels of viral replication.

Presented in part at the Digestive Disease Week session of the American Association for the Study of Liver Disease on Viral Hepatitis on 14 May 1989 in Washington, D.C. and published in abstract form (1989. Gastroenterology. 96:A676.).

Address reprint requests to Dr. Zeldis, Gastroenterology Division, Department of Internal Medicine, Room 2110, 4301 X Street, Sacramento, CA 95817. 1989

Received for publication 2 June 1989 and in revised form 10 August

1. Abbreviations used in this paper: $\mathrm{HBsAg}$, hepatitis B surface antigen; HBV, hepatitis B virus; PCR, polymerase chain reaction.

J. Clin. Invest.

(c) The American Society for Clinical Investigation, Inc.

$0021-9738 / 89 / 11 / 1503 / 06 \$ 2.00$

Volume 84, November 1989, 1503-1508
Prudent medical management must consider all $\mathrm{HBsAg}$ positive patients as infectious.

Recently, the polymerase chain reaction (PCR) for detecting DNA and RNA has allowed analysis of extremely small quantities of nucleic acid for the presence of sequences of interest $(1,2)$. A difficulty with employing PCR methodology to detect HBV DNA sequences is that sera contain inhibitors of DNA polymerase. This has necessitated the extraction and purification of nucleic acid before performing PCR $(3,4)$. Purification of nucleic acid is not totally efficient, often resulting in loss of nucleic acid sequences of interest.

We now describe a direct method of detecting serum HBV DNA by polymerase chain reaction. Less than 10 viruses can be identified. Furthermore, DNA can be directly sequenced from the amplified viral DNA. Using this method in two cases of acute self-limited hepatitis, surface antigenemia was found to precede viremia.

\section{Methods}

Sera and cells

HBsAg positive, HBV DNA positive sera were obtained from a variety of patients with chronic HBV infection. Sera were obtained from healthy blood donors at the Boston Beth Israel Hospital blood bank and the Sacramento Medical Foundation who had normal alanine aminotransferase (ALT), and no serological markers for HIV, HBV, and syphilis. The Sacramento Medical Foundation collected and saved plasma from volunteer $\mathrm{HBsAg}+$ blood donors. Through Abbott Laboratories, we obtained serial plasma samples from two plasmaphoresis donors who became HBsAg positive. These patients were frequently plasmaphoresed during the course of their acute self-limited hepatitis $B$ infection. All sera and plasma were stored at $-20^{\circ} \mathrm{C}$.

\section{Serological assays}

$\mathrm{HBsAg}$, anti-HBc IgM, and $\mathrm{HBeAg}$ were tested by commercial enzyme-linked immunoassays (Abbott Laboratories, North Chicago, IL). Pre-S2 antigen was assayed by a radioimmunoassay in which $200 \mu \mathrm{l}$ sera were incubated overnight at $20^{\circ} \mathrm{C}$ with beads from the Auszyme assay (Abbott Laboratories). After washing, ${ }^{125}$ I-labeled anti-pre-S2 monoclonal antibodies were incubated with the beads for $2 \mathrm{~h}$ at $40^{\circ} \mathrm{C}$, washed, then counted. A signal to noise ratio $(\mathrm{S} / \mathrm{N})$ of greater than 3.0 was considered positive.

Serum HBV DNA was detected both by the Abbott Genostics hepatitis B viral DNA assay (11) and by dot blot hybridization (5). The sensitivity of each assay is virtually equivalent. The HBV DNA dot blot analysis detects $\sim 0.1 \mathrm{pg} / 100 \mu \mathrm{l}$ of serum after 7-d autoradiography. We have found that our estimate of viral DNA concentration based on densitometry of autoradiograms of samples using cloned HBV DNA was within one $\log _{10}$ order of magnitude of the viral titer determined by electronmicroscopy, core protein concentration, or chimpanzee infectivity (unpublished results performed on reagents obtained from Merck, Sharp, Dohme, West Point, PA and with Immuno, Vienna, Austria). Faint signals at the limit of detectability $(0.1$ pg DNA) gave inconsistent results, not verifiable by the liquid hybridization assay; therefore, only spots that gave a signal after $24 \mathrm{~h}$ autoradiography (>1 pg signal) were scored positive. 


\section{Primers}

Fig. 1 lists the location, length, and orientation of the primers used to perform PCR. Some s gene sequences were derived from those supplied by J. Sninsky and D. Mack of Cetus Corp., Emeryville, CA. The other primer sequences were derived from published HBV DNA se-
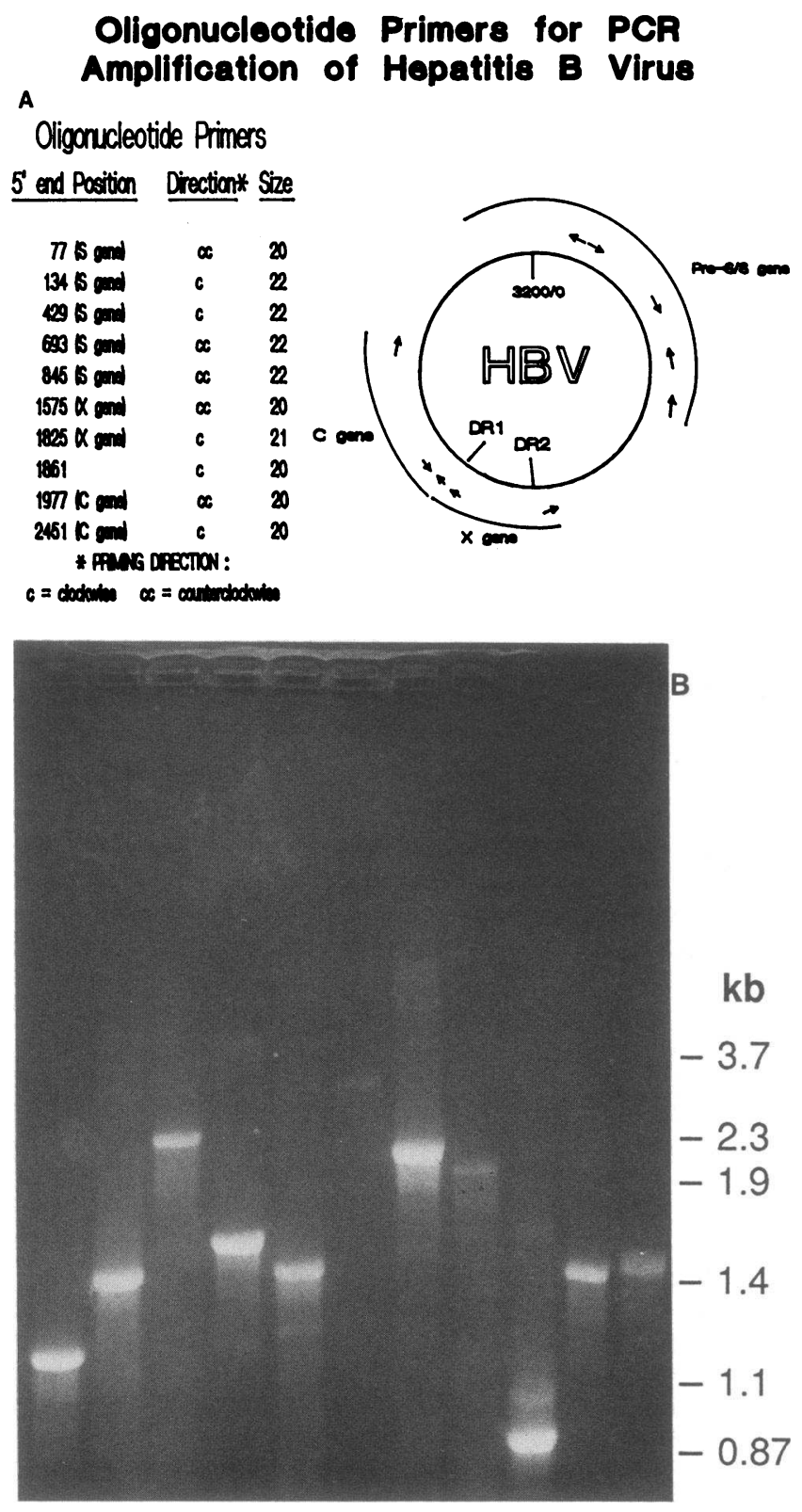

Figure 1. $(A)$ The location, length (size in base pairs), and orientation (direction) of the primers used to perform PCR on HBV DNA. The sequences used were based on consensus sequences using those published for adr $(15,16)$, adw (16), and ayw $(16,17)$. (B) Amplification of various segments of serum HBV DNA using different combinations of clockwise and counterclockwise primers. The fragments generated were from right to left: $1452 \mathrm{bp}$ (position 1825 to 77); $1417 \mathrm{bp}$ (position 1861 to 77); 927 (position 2451 to 77 ); 2132 (position 1861 to 692); 2285 (position 1861 to 845 ); 3015 (position 1861 to 1575 ); 1542 (position 2451 to 692 ); 1696 (position 2451 to 845 ); 2425 (position 2451 to 1575 ); 1441 (position 134 to 1575 ); 1146 (position 429 to 1575 ). Note that the sixth column from the left creates a $3015 \mathrm{nu}-$ cleotide fragment produced by priming from either side of the ends of the 1 strand of $\mathrm{HBV}$. quences analyzed from GenBank using alignment programs. (DNAStar, Madison, WI; 6) The oligonucleotide primers were synthesized by phosphoramidite chemistry.

\section{Polymerase chain reaction detection of serum HBV DNA}

In all assays, PBS, negative control sera from normal blood bank donors, and $1 \mathrm{ng}$ of cloned HBV DNA were analyzed. The samples were handled on a laboratory bench removed from the reagents used in the PCR to avoid contamination.

Nonspecific adsorption method. 50-100 $\mu \mathrm{l}$ of serum were incubated overnight at $20^{\circ} \mathrm{C}$ in a $0.5-\mathrm{ml}$ Eppendorf tube. The serum was then discarded and the tube washed three times with PBS. $16 \mu$ lof water and $100 \mu \mathrm{l}$ of mineral oil were added; the tube was heated to $95^{\circ} \mathrm{C}$ for 10 min. $3 \mu$ of 10 times PCR buffer $(500 \mathrm{mM} \mathrm{KCl}, 100 \mathrm{mM}$, Tris pH 8.3, $15 \mathrm{mM}, \mathrm{MgCl}_{2}, 0.1 \%$ (wt/vol) gelatin) were added, plus $10 \mu \mathrm{l}$ of a 250- $\mu \mathrm{g}$ per ml solution of proteinase $\mathrm{K}$ (Boehringer-Mannheim, Indianapolis, IN). The mixture was incubated at $60^{\circ} \mathrm{C}$ for $60 \mathrm{~min} .21 \mu \mathrm{l}$ of a "master mix" were added consisting of $9 \mu \mathrm{l}$ of water, $2 \mu \mathrm{l}$ of $10 \times$ PCR buffer, $8 \mu$ l of dNTP mix ( $1.5 \mathrm{mM}$ final concentration each of dATP, dCTP, dGTP, TTP, pH 7), $1 \mu$ l each of a clockwise and counterclockwise primer (final concentration of each primer is $\sim 1 \mu \mathrm{M}$ ). The reaction was heated to $95^{\circ} \mathrm{C}$ for $10 \mathrm{~min}$ both to denature the proteinase $K$ and to anneal primers to single stranded DNA, then cooled to $50^{\circ} \mathrm{C}$ for $5 \mathrm{~min} .5 \mu \mathrm{l}(0.5 \mathrm{U})$ of Taq DNA polymerase (Perkin Elmer-Cetus Corp., Norwalk, CT) were added. The reaction was cycled 40 times between $72^{\circ} \mathrm{C}$ for $30-180 \mathrm{~s}$ depending on the length of DNA being amplified, $95^{\circ} \mathrm{C}$ for $1 \mathrm{~min}$, and $50^{\circ} \mathrm{C}$ for $2 \mathrm{~min}$. After the 40 th cycle, the $72^{\circ} \mathrm{C}$ elongation step proceeded for an additional $10 \mathrm{~min}$. The mixture was heated to $95^{\circ} \mathrm{C}$ for $1 \mathrm{~min}$, then cooled to $4^{\circ} \mathrm{C}$ until analyzed by dot blot analysis, electrophoresis in $1.8 \%$ agarose in $1 \times$ TAE (40 mM Tris-acetate, pH 7, 2 mM EDTA) with $0.5 \mu \mathrm{g} / \mathrm{ml}$ ethidium bromide, Southern blot analysis, or liquid hybridization.

Antibody microparticle method. Carboxylated latex microparticles (0.1-0.3 $\mu \mathrm{m}$ diam) were obtained from Seradyne, Inc. (Indianapolis, IN). Monoclonal IgG or IgM molecules were covalently coupled to these microparticles using 1-ethyl-3-3 (dimethylaminopropyl) carbodiimide chemistry $(7,8)$. After coupling, microparticles were centrifuged for $15 \mathrm{~min}$ at $17,000 \mathrm{rpm}$ (JA19 rotor); supernatant decanted; and microparticles resuspended at $1.6 \% \mathrm{vol} / \mathrm{vol}$ in $150 \mathrm{mM}$ Tris, $\mathrm{pH}$ $8.0,100 \mathrm{mM} \mathrm{NaCl}, 0.5 \%$ gelatin, $0.1 \%$ Tween $20,9.5 \%$ sucrose, and $0.02 \% \mathrm{NaN}_{3}$.

$100-200 \mu \mathrm{l}$ of sera or plasma were incubated for $30 \mathrm{~min}$ at room temperature with a $25-\mu l$ suspension of microparticles (total surface area of $24-100 \mathrm{~cm}^{2}$ ) coated with monoclonal antibodies to $\mathrm{HBsAg}$, pre-S1 region of $\mathrm{HBsAg}$, pre-S2 region of $\mathrm{HBsAg}$, or biotin obtained from Abbott Laboratories. The microparticles were pelleted in a microcentrifuge, washed once with PBS, suspended in water, heated, digested with proteinase $\mathrm{K}$, and heated again as described above. The reaction mixture was centrifuged to pellet the microparticles. The supernatant was placed in another tube and PCR was performed as described. In some cases, the sera or plasma were centrifuged through a 0.9-ml spin column of Sephacryl 300 (Pharmacia Fine Chemicals, Piscataway, NJ) before adding the antibody-coated microparticles (9).

Oligonucleotide primers were end-labeled by $\mathrm{T} 4$ polynucleotide kinase in a total volume of $15 \mu$ l containing $15 \mathrm{mM}$ Tris pH 7.4, 10 $\mathrm{mM} \mathrm{MgCl}, 0.1 \mathrm{mM}$ EDTA, 0.1 spermidine, $5 \mathrm{mM}$ DTT and $75 \mu \mathrm{m}$ of gamma labeled $\left[{ }^{32} \mathrm{P}\right] \mathrm{dATP}$ at $3,000 \mathrm{mCi}$ per $\mathrm{mM}$. The mixture was heated to $65^{\circ} \mathrm{C}$ for $10 \mathrm{~min}$, then placed in ice for $2 \mathrm{~min} .1 \mu \mathrm{l}(\sim 5 \mathrm{U})$ of $\mathrm{T} 4$ polynucleotide kinase was added; reaction proceeded for $30 \mathrm{~min}$ at $37^{\circ} \mathrm{C}$; heated for $65^{\circ} \mathrm{C}$ for $10 \mathrm{~min}$; and then directly used for the hybridization. HBV DNA was nick translated as previously described (5).

\section{DNA sequencing of amplified DNA sequences}

After PCR, the reaction mixture was passed through a Sephadex G-50 spin column (9), then sequenced by the dideoxy method of Sanger using the Taq DNA polymerase according to manufacturers' instruction (10). (Taquence DNA sequencing kit; USB Corp., Cleveland, OH) 
using ${ }^{35}$ S-labeled dATP and 7\% polyacrylamide sequencing gels. The autoradiograms were analyzed using a SeqEasy digitizer and DNAStar software (DNAStar).

\section{Results}

As little as $5 \mu$ l of HBV DNA positive serum quenches a PCR reaction. We found that $P C R$ could directly detect serum $H B V$ DNA if the virus was first adsorbed onto a solid surface such as an Eppendorf tube or antibody-coated microparticles, followed by proteinase $\mathrm{K}$ digestion and denaturation of the proteinase K. Steps that were absolutely necessary for performing PCR on viral DNA sequences in serum included the initial $95^{\circ} \mathrm{C}$ treatment in water; the proteinase $\mathrm{K}$ treatment; and the subsequent 10 -min heat treatment that presumably denatures proteinase K. Fig. 1 demonstrates the lengths of different amplified DNA segments created by PCR using various clockwise and counterclockwise primer pairs originating in the $\mathrm{s}, \mathrm{c}$, and $\mathrm{x}$ regions on a HBV DNA containing serum. Since PCR often generates spurious DNA bands that range from 50 to 250 base pairs in length, primer pairs that create fragments greater than 400 base pairs long were primarily employed. 40 cycles were used to achieve greater than a million-fold amplification.

Siliconized Eppendorf tubes are as efficient in adsorbing virus as untreated polypropylene Eppendorf tubes based upon end point titration of the lowest concentration of virus needed for serum HBV DNA detection. Dilution of viral specimens in PBS was more sensitive than specimens diluted into serum. While serial dilution in PBS detected approximately three viruses per $100 \mu \mathrm{l}$ after electrophoresis, Southern blot transfer and probing with an end-labeled oligonucleotide. Serial dilution in serum found only 300 viruses per $100 \mu$ l using tube adsorption.

Viral adsorption to microparticles was found to be superior to Eppendorf tubes both because of their greater surface area (24 to $100 \mathrm{~cm}^{2}$ vs. 1.4 to $2.5 \mathrm{~cm}^{2}$ ) and because of antibody specific adsorption to coated microparticles. Fig. 2 shows the results of an experiment in which monoclonal anti-biotincoated microparticles could detect as little as 30 viruses in 200 $\mu \mathrm{l}$ of serum; while monoclonal anti-HBs-coated microparticles detected 3 viruses. The yield of amplified DNA using monoclonal anti-HBs, anti-pre-S1, and anti-pre-S2 coated microparticles was so great that ethidium bromide staining of the agarose gels was as sensitive as Southern blot analysis in detecting $<10$ virus per serum specimen. While most serum specimens did not have to be diluted in PBS to improve the sensitivity of the assay, occasionally the intensity (yield) of the ethidium bromide amplified DNA fragment would increase if the sample were diluted in PBS. The yield of amplified DNA and the sensitivity of the assay improved if serum or plasma was first passed through a Sephacryl 300 spin column before adsorption to microparticles.

Amplified DNA could be directly sequenced by the dideoxy method of Sanger (10). Using primers complementary to the s gene, a 690-bp fragment was amplified and sequenced from two HBV DNA positive sera, one of which lacked anti$\mathrm{HBc}$ antibody (Fig. 3). The HBsAg of each sera was adw subtype. The HBV DNA concentration of the anti-HBc negative sera was $\sim 20,000$ virus $/ \mathrm{ml}$ at the lower limit of sensitivity of a dot blot assay. While the other sera's amplified HBV DNA sequence was entirely identical to the published adw sequence (6), the anti-HBc negative sera was $>98 \%$ the same. When

\section{Limit of Detection of Anti-Biotin Coated Microparticles}
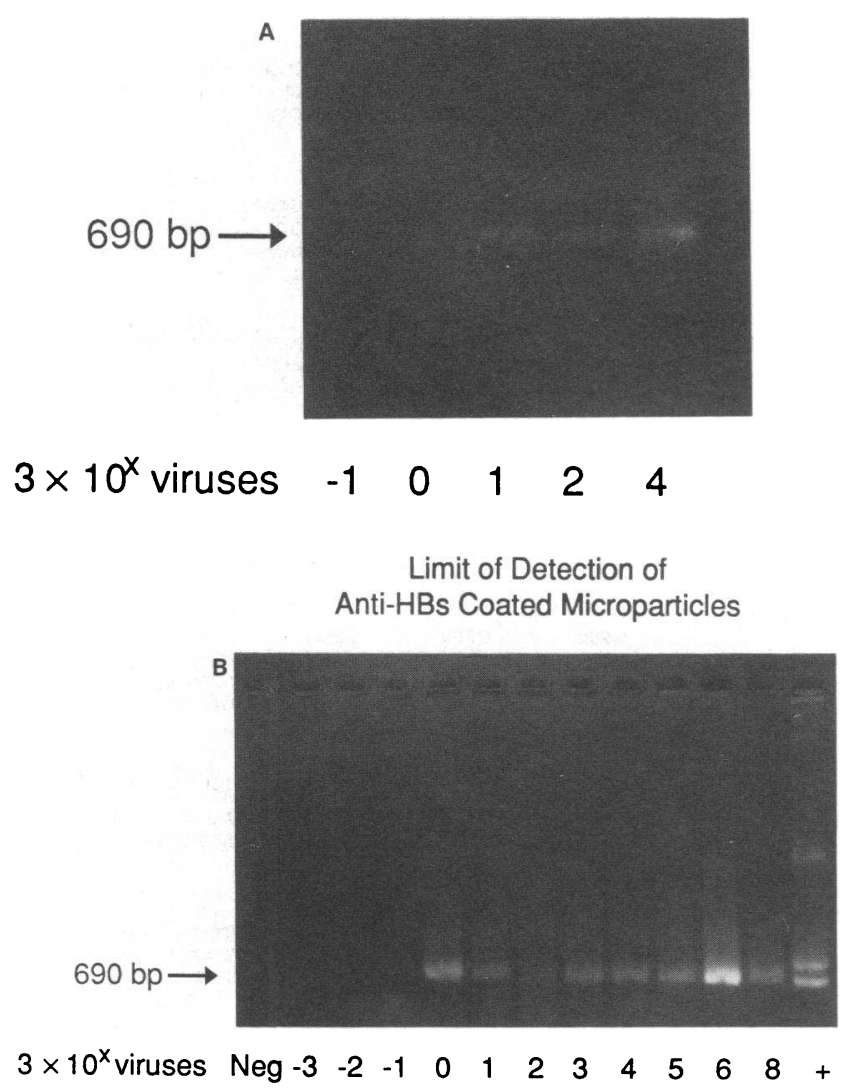

Figure 2. Comparison of the sensitivity of anti-biotin coated microparticles $(A)$ versus that of anti-HBs coated microparticles $(B)$ in detecting serum HBV DNA. $200 \mu \mathrm{l}$ of HBV DNA positive serum serially diluted in control serum was analyzed for HBV DNA as described in Methods using two primers in the s gene that were 690 nucleotides apart.

translated, the sequence of the 57 amino acid segment only differed by one amino acid (tyrosine versus phenylalanine in position 213).

45 sera that were obtained from healthy blood donors and that had normal ALT and negative serologies for HBV, HIV, and syphilis had no detectable amplified DNA using HBV specific oligonucleotide primers using either the Eppendorf tube or microparticle methods to adsorb virus before performing PCR. Rarely, negative control sera scored positive and the results of the entire experiment were discarded because of possible contamination of PCR reagents. More than $40 \mathrm{HBsAg}+$ sera were analyzed for HBV DNA by both dot blot and PCR. In every instance in which sera were positive by dot blot assay, PCR methodology using either the antibody-coated microparticle or Eppendorf tubes also produced a positive signal. Conversely, we identified $\mathrm{HBsAg}$ positive serum samples that were HBV DNA positive by PCR but negative by dot blot assay. Table I summarizes the assay results for HBV DNA performed by the dot blot, liquid hybridization, and PCR methods of 24 HBsAg+ blood donors. Seven were HBV DNA positive by either liquid hybridization or dot blot assay. In cases 8 and 22, the results of each assay differed. PCR analysis identified all 
A

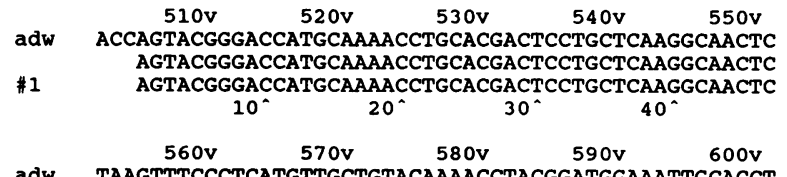

adw TAAGTTCCCTCATGTTGCTGTACAAAACCTACGGATGGAATTGCACCT

TAAGTTTCCCTCATGTTGCTGTACAAAACCTACGGATGGAAATTGCACCT

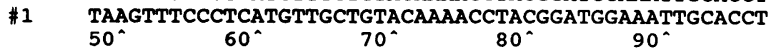

adw GTATTCCCATCCCATCGTCCTGGGCTTTCGCAAAATACCTATGGGAGTGG

GTATTCCCATCCCATCGTCCTGGGCTTTCGCAAAATACCTATGGGAGTGG

\# 1 GTATTCCCATCCCATCGTCCTGGGCTTTCGAAAATACCTATGGGAGTGG

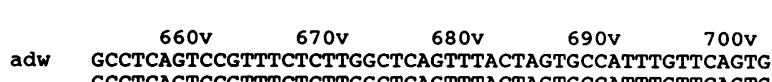

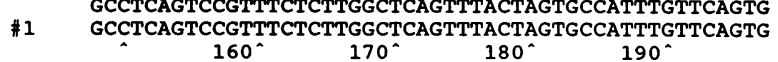

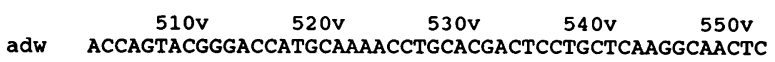
\#2 ACCTGCACGACTCCTGCTCAAGGCAACTC
ACCTGCACGACTCCTGCTCAAGGCAACTC

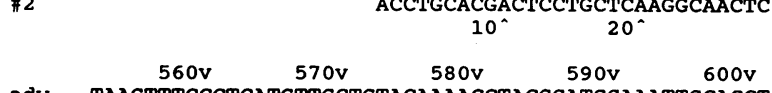

adW TAAGTTTCCCTCATGTTGCTGTACAAAACCTACGGATGGAAATTGCACCT

\#2 TAAGTTTCCCTCATGTTGCTGTACAAAACCTACGGATGGAAATTGCACCT TAAGTTTCCCTCATGTTGCTGTACAAAACCTACGGATGGAAATTGCACCT . $40^{\circ} \quad 50^{\circ} 60^{\circ}$ $610 \mathrm{~V} 620 \mathrm{v} 630 \mathrm{v} 650 \mathrm{~V} \quad 650 \mathrm{v}$

adw GTATTCCCATCCCATCGTCCTGGGCTTTCGCAAAATACCTATGGGAGTGG

adw GTATTCCCATCCCATCGTCCTGGGCTTTCGCAAAATACCTATGGGAGTGG $\# 2$ GTATTCCCATCCCATCATCCTGGGTTTCGCAAAATTCCTATGGGAGTGG
$90^{\circ}$
$100^{\circ}$

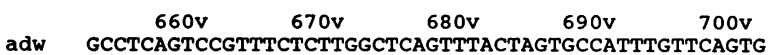

GCCTCAGTCCGTTTCTC TGGCTCAGTTTACTAGTGCCATTTG

\#1 GCCTCAGTCCGTTTCTCCTGGCTCAGTTTACTAGTGCCATTTG

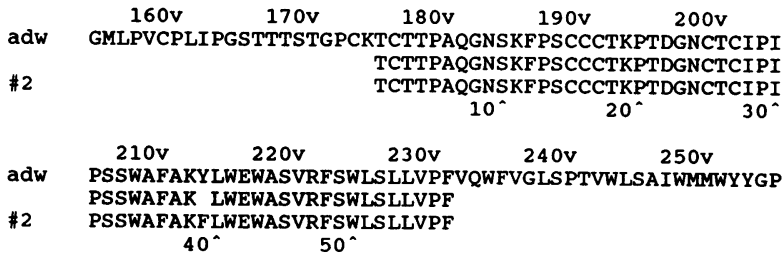

Figure 3. Comparison of the nucleic and amino acid sequences of the amplified serum HBV DNA fragments obtained after PCR to sequences published for hepatitis B virus, subtype adw (16). $(A)$ The nucleotide sequence of a 191 base sequence from serum 1 , subtype adw $\mathrm{HBs} \mathrm{Ag}+, \mathrm{HBeAg}+$, anti-HBc+ serum, is identical to that of adw. $(B)$ The nucleotide sequence of a 172 base sequence from serum 2, a subtype adw $\mathrm{HBsAg}+$, anti-HBc- serum, is $98.256 \%$ identical to that of adw. $(C)$ The 57 amino acid sequence translated from the nucleic acid sequence in $b$ is identical to that of adw (16) except in position 213 in which a phenylalanine $(F)$ is substituted for a tyrosine (Y).

HBV DNA positive samples by these methods as well as case 16 that the other assays scored as negative. These samples and others were obtained from a variety of sources and clinical correlations were not available. 29 plasma samples from two patients with acute self-limited hepatitis were also blindly analyzed for HBV DNA either by PCR or by a liquid hybridization assay as sensitive as the dot blot method (11). (Table II) Three samples were positive by liquid hybridization and six by PCR analysis. There were no false positive samples by either assay. For each patient, $\mathrm{HBsAg}$ and pre-S2 antigenemia preceded serum HBV DNA. In one, viremia was found after the patient was no longer $\mathrm{HBs} A g+(1 / 31 / 89$, patient $\mathrm{E})$.
Table I. Analysis of HBsAg+ Blood Donors

\begin{tabular}{rrrrrrr}
\hline & & \multicolumn{2}{c}{ HBV DNA } & & \\
\cline { 3 - 6 } Number & ALT & HBeAg & Dot blot & L.H. & PCR" \\
\hline 1 & 13 & - & - & - & - \\
2 & 30 & - & - & - & - \\
3 & 13 & - & - & - & - \\
4 & 25 & - & - & - & - \\
5 & 25 & - & - & - & - \\
6 & ND & - & - & - & - \\
7 & 25 & + & + & + & + \\
8 & 100 & + & + & - & + \\
9 & 12 & - & - & - & - \\
10 & 26 & - & - & - & - \\
11 & 14 & - & - & - & - \\
12 & 7 & - & - & - & - \\
13 & 13 & - & - & - & - \\
14 & 13 & - & - & - & - \\
15 & $<54$ & - & - & - & - \\
16 & 599 & + & - & - & + \\
17 & 113 & - & - & - & - \\
18 & $<54$ & + & + & + & + \\
19 & $<54$ & + & - & - & - \\
20 & $<54$ & + & + & + & + \\
21 & 7 & + & + & + & + \\
22 & $<54$ & + & - & + & + \\
23 & 22 & + & + & + & + \\
24 & $<54$ & + & + & + & + \\
& & & & &
\end{tabular}

* All samples were anti-HBc+ except for samples 21 and 23. ND, Assay not performed.

${ }^{\ddagger}$ Dot blot performed as described in Methods. Borderline positive spots ( $<1 \mathrm{pg}$ density) were scored as negative.

$\S$ Results of Abbott Genostics HBV DNA assay.

"The s gene primers generated a DNA fragment that was $690 \mathrm{bp}$ long. Anti-HBs coated microparticles were employed after passing $100 \mu 1$ sample through a $0.9-\mathrm{ml}$ Sephacryl 300 spin column as described in Methods.

\section{Discussion}

Polymerase chain reaction is unable to be performed in serum because serum substances inhibit DNA polymerase activity. By adsorbing virus to a solid surface, washing the surface, then destroying the remaining proteins with proteinase $K$, we have found that PCR could detect serum HBV DNA at concentrations below the sensitivity of conventional dot blot and liquid hybridization assays. Desalting serum or plasma through a Sephacryl 300 spin column before adsorption also increased the sensitivity of the assay. A rough quantitation of viral DNA can be estimated by serially diluting a sample in HBV DNA negative serum or PBS. As little as three viruses per $200 \mu \mathrm{l}$ were detected using anti-HBs-, anti-pre-S1-, or anti-pre-S2-coated microparticles.

A variety of highly sensitive serological assays for antigens, antibodies, and nucleic acids are available for both the clinician and researcher. While $\mathrm{HBeAg}$ positivity correlates with high titer serum HBV DNA in chronic HBsAg carriers, the absence of $\mathrm{HBeAg}$ or antibody to $\mathrm{HBeAg}$ does not exclude the presence of serum hepatitis B virus DNA (5). We have found 
Table II. A Blind Analysis of Plasma from Two Patients with Acute $\mathrm{HBV}$

\begin{tabular}{|c|c|c|c|c|c|}
\hline \multirow[b]{2}{*}{ Date } & \multirow[b]{2}{*}{ HBsAg } & \multirow[b]{2}{*}{ Pre-S2* } & \multirow[b]{2}{*}{$\begin{array}{c}\text { Anti-HBc } \\
\text { IgM }\end{array}$} & \multicolumn{2}{|c|}{ HBV DNA } \\
\hline & & & & L.H..$^{\ddagger}$ & $\mathrm{PCR}^{\S}$ \\
\hline \multicolumn{6}{|l|}{ Patient E } \\
\hline $11 / 25 / 88$ & - & - & - & - & - \\
\hline $11 / 29$ & - & - & - & - & - \\
\hline $12 / 2$ & + & $+1-$ & - & - & - \\
\hline $12 / 6$ & + & 44 & - & - & - \\
\hline $1 / 10 / 89$ & + & 2270 & - & + & + \\
\hline $1 / 19$ & + & 112 & - & - & + \\
\hline $1 / 24$ & + & - & + & - & + \\
\hline $1 / 31$ & - & - & + & - & + \\
\hline $2 / 7$ & - & - & + & - & - \\
\hline $2 / 14$ & - & - & + & - & - \\
\hline $2 / 21$ & - & - & + & - & - \\
\hline $2 / 28$ & - & - & + & - & - \\
\hline $3 / 7$ & - & - & + & - & - \\
\hline $3 / 14$ & - & - & + & - & - \\
\hline $3 / 21$ & - & - & + & - & - \\
\hline $3 / 25$ & - & - & + & - & - \\
\hline $4 / 4$ & - & - & + & - & - \\
\hline $4 / 11$ & - & - & - & - & - \\
\hline $4 / 18$ & - & - & - & - & - \\
\hline $4 / 25$ & - & - & - & - & - \\
\hline $5 / 2$ & - & - & - & - & - \\
\hline $5 / 9$ & - & - & - & - & - \\
\hline $5 / 16$ & - & - & - & - & - \\
\hline $5 / 30$ & - & - & - & - & - \\
\hline Neg. Control & - & - & - & - & - \\
\hline Neg. Control & - & - & - & - & - \\
\hline \multicolumn{6}{|l|}{ Patient L } \\
\hline $1 / 26 / 88$ & - & - & ND & - & - \\
\hline $1 / 31$ & + & 18 & ND & - & - \\
\hline $2 / 2$ & + & 32 & ND & - & - \\
\hline $3 / 27$ & + & 660 & ND & + & + \\
\hline $4 / 5$ & + & 685 & ND & + & + \\
\hline Neg. Control & - & - & ND & - & - \\
\hline Neg. Control & - & - & ND & - & - \\
\hline
\end{tabular}

* The pre-S2 assay was performed as described in Methods. Listed are the $\mathrm{S} / \mathrm{N}$ ratio.

Results of Abbot Genostics HBV DNA assay.

The s gene primers generated a DNA fragment that was 690 bp long. AntiHBs coated microparticles were employed after passing $100 \mu \mathrm{l}$ sample through a 0.9-ml Sephacryl 300 spin column as described in Methods. ND, Assay not performed.

that $\sim 20 \%$ of chronic $\mathrm{HBsAg}$, anti-HBe positive cirrhotics will be serum HBV DNA positive as judged by conventional spot hybridization assay. With development of an even more sensitive polymerase chain reaction assay, a higher percentage of patients may be found to contain circulating viral DNA and therefore be potentially infectious.

The increased sensitivity of the PCR assay is illustrated by Tables I and II in which this method identified all sera and plasma identified as HBV DNA positive by liquid hybridization and dot blot analyses and identified some samples not scored positive by either assay. In the survey of $24 \mathrm{HBsAg}+$ blood donors (Table I), only $\mathrm{HBeAg}+$ samples were $\mathrm{HBV}$ DNA+. In two cases of acute infection (Table II), hepatitis B surface and pre-S2 antigenemia preceded serum HBV DNA. This does not necessarily reflect the greater sensitivity of the immunoassays for HBsAg and pre-S2 antigen, since a plasma sample obtained over 2 mo into the infection ( $1 / 31 / 89$, patient
E) was viremic and not antigenemic. During HBV infections, the liver usually synthesizes excess HBsAg that are found free of virions. These 22-nm and pencil shaped antigen complexes are composed of the major (small S) and pre-S2-S (middle S) forms of $\mathrm{HBsAg}$. Our results suggest that surface antigenemia might normally precede viremia in acute hepatitis $\mathrm{B}$. In the early stages of infection, viral uptake by uninfected cells may consume the HBV that is released from hepatocytes while allowing the antigen complexes to circulate; thus resulting in antigenemia preceding viremia. More episodes of early acute hepatitis $B$ infection need to be studied before concluding that in most cases antigenemia precedes viremia; however, our results show that viremia can transiently persist beyond antigenemia.

The advantage of the method described above is that $100-200 \mu l$ of serum can be readily evaluated for the presence of HBV DNA with minimal manipulation. Depending on whether serum is diluted in PBS or serum and depending on the adsorptive surface (Eppendorf tubes vs. antibody-coated microparticles), the sensitivity of our method of performing PCR is $\sim 10$ - to 1,000 -fold more sensitive than conventional hybridization assays. DNA dot hybridization assays are one dimensional. Serum samples that contain large quantities of chromosomal and other types of DNA are often falsely scored positive by dot blot assay due to nonspecific adsorption of probe. PCR on normal human chromosomal DNA with HBV DNA specific primers fail to produce positive signals, that is, a band at the exact molecular weight expected for the oligonucleotide primers used (data not shown). Thus PCR is both more sensitive and specific than liquid and dot blot hybridization assays. Despite published documentation that low concentrations of viral DNA may be detected by PCR after extraction and precipitation $(3,4)$, we have found that this method is at least 100 -fold less sensitive as the antibody-coated microparticle technique (data not shown). Another advantage of the microparticle technique is that it is only able to detect virally encapsulated DNA since antibody-coated microparticles are used to capture the virion. Chromosomal DNA that sometimes is present in serum are not included in the PCR.

The sensitivity of PCR approaches the lower limit of infectivity of hepatitis B virus in chimpanzees. Since not all $\mathrm{HBsAg}$ positive patients are actively replicating virus but may have integrated viral DNA that act as transcripts for surface antigen (12-14), it is theoretically possible that PCR analysis may distinguish infectious from noninfectious individuals. Reduction of this to clinical practice is not warranted since some patients may have episomal viral DNA that is not actively producing virions. These patients may be temporarily serum HBV DNA negative only to have reactivation of viral replication at a later time. Thus, despite the availability of a rapid and an extremely sensitive assay for serum HBV DNA, the absence of a viral DNA signal should not exclude the possibility that an $\mathrm{HBsAg}$ positive patient is no longer infectious for hepatitis $B$ virus.

A major obstacle to the universal adoption of PCR for detecting serum HBV DNA is its extreme sensitivity. Miniscule contamination of samples or reagents with even a single DNA molecule can result in a false positive signal. We have, therefore, had to resort to handling specimens in different locations than the PCR reagents and using multiple negative and positive controls with each PCR trial. The data for a trial was discarded if any controls' results were false. In most instances, each serum sample was analyzed more than once at both neat 
and one-tenth dilution. In this way, we could be confident about the validity of our results.

The utility of PCR lies in the rapid and sensitive detection of HBV DNA sequences from small quantities of biological fluids and cells. We have previously described an infection model for HBV DNA using hemopoietic stem cells (18). We are now able to assay these stem cells for the presence of $\mathrm{HBV}$ DNA as well as the production and secretion of small quantities of viral particles. Here we present data regarding the rapid isolation and sequencing of a segment of the s gene from a patient with abnormal hepatitis B virus serology (i.e., anti-HBc negative, HBsAg positive). Our microparticle methodology should allow the sequencing of the entire HBV genome from such patients. Furthermore, this PCR method coupled with dideoxy sequencing should allow verification that cells are infected by viruses produced in HepG 2 transformants modified by site specific mutagenesis.

In conclusion, we describe a method for detecting $\mathrm{HBV}$ DNA in serum by the polymerase chain reaction. An advantage of this method is that it can be performed on serum with minimal manipulation and without having to extract and precipitate nucleic acid. The ability to detect only a few HBV DNA molecules should allow a redefinition of the virology and course of hepatitis B infection. Direct PCR detection of viral nucleic acid by adsorption to a solid matrix should be applicable for the diagnosis of a variety of viremias.

\section{Acknowledgments}

We would like to thank John Sninsky and David Mack of the Cetus Corp., Emeryville, CA for their advice on HBV DNA oligonucleotide probes and on how to perform PCR on extracted nucleic acids. We are grateful to Marco Floreani for excellent technical help in developing the Pre-S2 antigen assay and for preparing antibody coated microparticles. We would like to thank Paul Holland for use of sera and plasma collected at the Sacramento Medical Foundation.

Part of this work was funded by the Hans Popper Scholar Award of the American Liver Foundation and National Institutes of Health grant HL-01917.

\section{References}

1. Saiki, R., D. Gelfand, S. Stoffel, S. Scharf, R. Higuchi, G. Horn, K. Mullis, and H. Erlich. 1988. Primer directed enzymatic amplification of DNA with a thermostable DNA polymerase. Science (Wash. DC). 239:487-491.

2. Ou, C.-Y., S. Kwok, S. Mitchell, D. Mack, J. Sninsky, J. Krebs, P. Feorino, D. Warfield, and G. Schochetman. 1988. DNA amplification for direct detection of human immunodeficiency virus 1 (HIV-1) in DNA of peripheral mononuclear cells. Science (Wash. DC). 239:295-297.

3. Kaneko, S., R. H. Miller, S. M. Feinstone, M. Unoura, K. Ko- bayashi, N. Hattori, and R. H. Purcell. 1989. Detection of serum hepatitis B virus DNA in patients with chronic hepatitis using the polymerase chain reaction assay. Proc. Natl. Acad. Sci. USA. 86:312316.

4. Theirs, V., E. Nakajima, D. Kremsdorf, D. Mack, H. Schellekens, F. Driss, A. Goudeau, J. Wands, J. Sninsky, P. Tiollais, and C. Brechot. 1988. Transmission of hepatitis B from hepatitis B seronegative subjects. Lancet. ii:1273-1276.

5. Zeldis, J. B., E. Ben-Porath, R. Enat, K. Kirsch, and J. Wands. 1986. Correlation of HBV DNA and monoclonal reactivity to $\mathrm{HBsAg}$ in serum of patients with HBV infection. Virol. Methods. 14:152-166.

6. Ono, Y., H. Onda, R. Sasada, K. Igarashi, Y. Sugino, and K. Nishioka. 1983. The complete nucleotide sequences of the cloned hepatitis B virus DNA; subtype adr and adw. Nucleic Acid Res. 11:17471757.

7. Nathan, C. F., and Z. A. Cohn. 1981. Antitumor effects of hydrogen peroxide in vivo. J. Exp. Med. 154:1539-1553.

8. Quash, G., A. M. Roch, A. Nivekau, J. Grange, T. Keolouangkahot, and J. Huppert. 1978. The preparation of latex particles with covalently bound polyamines, IgG and measles agglutinins and their use in viral agglutination tests. J. Immunol. Methods. 22:165-174.

9. Maniatis, T., E. F. Fritsch, and J. Sambrook. 1982. Molecular cloning: A laboratory manual. Cold Spring Harbor Laboratory, Cold Spring Harbor, NY. 545 pp.

10. Sanger, F., S. Nicklen, and A. R. Coulsen. 1987. DNA sequencing with chain terminating inhibitors. Proc. Natl. Acad. Sci. USA. 74:5463-5467.

11. Kuhns, M. C., A. L. McNamara, C. M. Cabal, R. H. Decker, V. Thiers, C. Brechot, and P. Tiollais. 1988. A new assay for the quantitative detection of hepatitis B viral DNA in human serum. In Viral Hepatitis and Liver Disease. A. J. Zuckerman, editor. Alan R. Liss, Inc., New York. 258-262.

12. Brechot, C., M. Hadchouel, J. Scotto, F. Degos, P. Charnay, C. Trepo, and P. Tiollais. 1981. Detection of hepatitis B virus DNA in liver and serum: A direct appraisal of the chronic carrier state. Lancet. ii:765-767.

13. Kam, W., L. B. Rall, E. A. Smuckler, R. Schmid, and W. J. Rutter. 1982. Hepatitis B viral DNA in liver and serum of asymptomatic carriers. Proc. Natl. Acad. Sci. USA. 79:7522-7526.

14. Hadziyannis, S. J., H. M. Lieberman, G. G. Karvountzis, and D. A. Shafritz. 1983. Analysis of liver disease, nuclear HBsAg, viral replication, and hepatitis $B$ virus DNA in liver and serum of $\mathrm{HBeAg}$ vs. anti-Hbe positive carriers of hepatitis B virus. Hepatology. 3:656-662.

15. Fujiyama, A., A. Miyanohara, C. Nozaki, T. Yoneyama, N. Ohtoma, and K. Matsubara. 1983. Cloning and structural analyses of hepatitis B virus DNAs, subtype adr. Nucleic Acid Res. 11:4601-4610.

16. Galibert, F., E. Mandart, F. Fitoussi, P. Tiollais, and P. Charney: 1979. Nucleotide sequence of the hepatitis B virus genome (subtype ayw) clone in E. coli. Nature (Lond.). 281:646-650.

17. Bichko, V., D. Dreilina, P. Pushko, P. Pumpen, and E. Gren. 1985. Subtype ayw variant of hepatitis B virus. FEBS (Fed. Eur. Biochem. Soc.) Lett. 185:208-212.

18. Zeldis, J. B., H. Mugishima, H. Steinberg, E. Nir, and R. P. Gale. 1986. In vitro hepatitis $B$ virus infection of human bone marrow cells. J. Clin. Invest. 78:411-417. 